The Canadian Journal of Higher Education, Vol. XXIII-2, 1993

La revue canadienne d'enseignement supérieur, Vol. XXIII-2, 1993

\title{
Attributes of Effective Lecturing in the College Classroom
}

\section{DIETER J. SCHONWETTER*}

\begin{abstract}
The following paper highlights research on effective lecturing in the college classroom. First, critical issues concerning the operational definition of effective lecturing and the measurement criteria used to denote it are addressed. Next, major research findings are reported. beginning with correlational information reported by descriptive studies and ending with causal findings demonstrated by empirical studies. Current research literature identifies the following lecture attributes as important for student learning: expressiveness, clarity, and organization. These dimensions are defined by low-inference behaviours and supported by empirical studies. Furthermore, links between lecture attributes and certain student cognitive processing activities, explaining the facilitative qualities of effective lecturing on student learning, are hypothesized. Finally, implications for both practitioners and researchers are discussed.
\end{abstract}

* Centre for Higher Education Research and Development, University of Manitoba. Correspondence should be addressed to Social Science Department, Columbia Bible College. Clearbrook. B.C., V2T 228. The author appreciates the insightful recommendations put forth by Jurgen F. Schonwetter, Raymond P. Perry, Verena H. Menec, and C. Ward Struthers on earlier versions of this manuscript. Also acknowledged are the two anonymous reviewers who provided many useful suggestions. This paper was written while the author was in receipt of a Social Sciences and Humanities Research Council Doctoral Fellowship. 


\section{Résumé}

Cet article présente les résultats des recherches portant sur les attributs du cours magistral par rapport à son efficacité dans la salle de cours au niveau universitaire. D'abord. les questions liées à la définition opérationnelle du concept sont présentées ainsi que les critères servant à le mesurer. Ensuite, les résultats des recherches importantes sur le sujet sont rapportés en commençant par les analyses de corrélation effectuées dans le contexte d'études descriptives et en terminant par les résultats de type causal obtenus dans le cadre d'études empiriques. Un examen de la documentation récente identifie trois attributs du cours magistral qui influence de façon importante l'apprentissage étudiant soit l'expressivité, la clarté et l'organisation du cours. Ces dimensions découlent de comportements "à basse inférence" et sont confirmées par les études empiriques. De plu, on émet des hypothèses sur les liens entre les attributs du cours magistral et certaines activités liés aux processus cognitifs des étudiantses qui expliqueraient l'effet du cours magistral efficace sur l'apprentissage étudiant.

\section{Attributes of Effective Lecturing in the College Classroom}

Educational researchers and social psychologists have spent considerable time and energy trying to delineate the factors which constitute effective lecturing in the college classroom. From this research, it is now widely accepted that certain lecture attributes have a profound effect on student cognition, affect, and behaviour (Feldman, 1989; Murray, 1991; Perry, 1991). The purpose of the following paper is to highlight the findings, focusing on research in the college classroom. Of the various methods of teaching available in higher education - which include discussion methods, seminars, and media (i.e., computer; television; video: audio; printed material) - lecturing continues to be the pervasive method of instruction in the university classroom (Dunkin \& Barnes, 1986). Given that most research studies investigate the lecture method only, it will be the focus of the paper. The following issues will be addressed: operational definition of the classic lecture; criteria used to identify and measure it; effective lecture attributes identified in current research; and postulates about the links between these and student learning. Finally, implications for lecturing in higher education and directions for future research are discussed. 


\section{Definitional Issues}

Conceptual obstacles in the delineation of effective lecturing variables, specifically the failure to define operationally what the classical lecture is, plague research in higher education. This issue stems from the difficulty apparent in the general rubric under which the classic lecture falls: effective teaching. Therefore, in order better to understand this issue, it is necessary to appreciate the attempts made to define effective teaching. For instance, Donald (1985) states that effective teaching is teaching that meets certain criteria - that is, factors or characteristics can be measured according to a standard.

A number of earlier researchers (Hildebrand, Wilson, \& Dienst, 1971: Wotruba \& Wright. 1974) have used as standards the subjective responses of faculty, administrators, students, and alumni to the question of "What are the effective characteristics of good teachers?" Such standards, however, are not uniform. For instance, each respondent represents a unique set of criteria (i.e., past experiences, personal biases) from which the responses are generated. Only recently has this "vagueness" been addressed. Murray (1991) defined teacher effectiveness research as the study of relationships between instructional behaviours of teachers (one being the classic lecture) and the educational changes occurring in students, such as achievement outcomes. He supports his definition in a recent empirical review of teaching literature in which he demonstrates that effective teaching has a significant effect on both student evaluation of instruction and student achievement. Thus. he defines effective teaching as the pedagogical behaviours that have an effect on students' scholastic performance or produce scholastic gains. The classic lecture, which represents one format of teaching. is the delivery of a discourse before an audience for instructional purposes. Effective lecturing, according to Murray's definition, would therefore be defined as the behaviours which occur in the delivery of the discourse, that have an effect on students' scholastic performance or performance gains.

Another obstacle plaguing previous research is the focus on global, nonspecific attributes of effective teaching and lecturing - such as expressiveness, clarity, and organization (Feldman, 1976; Marsh, 1984). These high inference behaviours can only be discerned by trained observers; they do not yield readily to interpretation as diagnostic feedback to instructors; they are not easily communicated to new instructors desiring to use the lecture method; and they are difficult to manipulate in experimental research. Murray (1983) has flagged researchers' attention to the need to conceptualize effective teaching attributes in terms of more specific, low-inference classroom behaviours; that is, denotable behaviours of the lecturer requiring minimal inference. Low-inference 
behaviours, in turn, are easily observed, recorded, operationalized, and manipulated for the purpose of observational or experimental research (Rosenshine \& Furst, 1971), and have the potential of being modified through feedback and training. Therefore, a concise operational definition that takes into account the relationship between lecturing behaviours and student learning outcomes, allowing for the identification of specific denotable lecturing behaviours, is important for research in higher education.

\section{Criteria For Measurement}

In conjunction with the operational definition of effective lecturing are the criteria or outcome measures used as standards. These include student cognitive criteria such as increased selective attention to material being presented; enhancement of problem-solving skills; gains in knowledge; positive evaluation of instructor; attitudinal or affective criteria, such as changes in pride, competence, and satisfaction: and increased motivation to learn (McKeachie, 1980b; Murray, 1991; Schonwetter, Perry \& Struthers, 1993). Other criteria that have been studied are course enrollment, class attendance (Leventhal, Abrami, Perry, \& Breen, 1975; Perry \& Penner, 1990), and study habits (Perry \& Penner, 1990; McKeachie, 1980a). The enhancement of student learning, particularly if deduced from an objective, reliable, and valid test, tends to be the most widely accepted standard against which to measure effective lecturing. Donald (1983) suggests that the strongest measure of student learning would be the gain in course knowledge between the beginning and the end of a course. For example, students gained knowledge of key concepts ranging from 3-38\% $(\mathrm{M}=18 \%)$, a gain that was found to be statistically significant in a number of introductory university courses (Donald, 1985).

However, using student learning as an indicator of effective lecturing has its shortcomings. Most observational and experimental studies thus far have relied almost exclusively on student final examinations as student learning measures. According to Murray (1991), final examinations do not differentiate the effects of lecturing. First, these examinations are based primarily on textbook material and, therefore, are not a good indicator of classroom learning; and second, the motivation to excel may be so high that students may try to compensate for ineffective teaching through means such as self-study, getting help from peers, etc., thereby washing out any lecturing effect (McKeachie, Pintrich, Lin, \& Smith, 1986). Furthermore, final examination scores cannot be compared across disciplines, across different courses within the same discipline, or even across the same course taught by different instructors (Marsh \& Dunkin, 1991), a situation which adds to the complexity of defining a standard by which 
effective teaching can be compared within and across disciplines. Also, the majority of teacher-made achievement tests assessing student leaming often measure low-level educational objectives such as memory of facts and definitions, rather than higher-level outcomes such as critical thinking and problemsolving - the latter of which are perceived as important by contemporary cognitive and educational psychologists in higher education (McKeachie, 1987). Finally, there is a lack of provision for determining the degree of existing knowledge that students have prior to the presentation of the material or for a measuring of information gain. Given these weaknesses, the studies reviewed in this paper are only first steps, albeit important ones, toward discovering the influence of effective lecture characteristics on student learning.

Instructor evaluations by students and alumni have also been widely accepted as a standard against which to measure lecturing effectiveness. Following twelve years of basic education, thousands of hours of instruction, and exposure to a number of different teachers, college students are assumed to have developed a concept of effective instruction by which they can discriminate among college lecturers. Accordingly, Perry (1985) argues that students are reasonably consistent and accurate judges of lecturing effectiveness. Empirical evidence supports this assumption in that student evaluations tend to be substantially reliable, valid, and relatively free from bias (see Cashin, 1988; Doyle 1983; Gigliotti \& Buchtel, 1990); tend to be valid predictors of student achievement or motivation to leam (Bolton, Bunge, \& Marr, 1979; Marsh, 1983; Marsh \& Overall, 1980); and tend to be moderately valid as predictors of educational objectives such as student knowledge gain (Cohen, 1981) or student achievement (Feldman, 1989; Murray, 1985; Perry, 1991). Finally, given that students value course achievement (Abrami. 1983; Perry, 1985), effective lecturers who enhance student achievement should receive high ratings from students. Therefore, student ratings of effective teaching are reasonably consistent and fairly accurate in discriminating low-inference behaviours constituting effective teaching.

\section{Profile of an Effective Lecturer: From Descriptive to Empirical Findings}

Research on lecturing basically consists of two methodological approaches: observational and experimental. In observational studies, behaviours are observed and recorded, and correlations are drawn between lecturing behaviours and student outcome measures. Dealing with "real" lecturers in "real" classroom settings, generalization of results is possible, but not without the 
difficulty of interpreting the results in terms of cause-and-effect language. The experimental approach, which manipulates one or more lecturing behaviours while holding all other factors constant, more readily allows a causal language interpretation, but at the cost of using a "contrived" or "artificial" condition that does not always allow for generalizations to real classroom situations. Rather than attempting an exhaustive review of the research to date, this paper will focus on the important studies that exemplify these research approaches (for a more detailed review, see Feldman, 1989; Marsh \& Dunkin, 1991; McKeachie, 1990a, 1990b; Murray, 1991; Perry 1991).

\section{Descriptive Studies}

Research on effective lecturing was initially descriptive and unstructured, relying on students' spontaneous open-ended responses rather than on a structured closed-ended questionnaire. For instance, students were asked to describe their ideal lecturers in terms of the characteristics that identified them as excellent (Epstein, 1981; Hildebrand et al., 1971; Sheffield, 1974). A myriad descriptions was revealed. Outstanding lecturers had "individual styles, using socrating, teasing. sonorous lecturing, sympathetic discussions, passionate argument, witty exposition, dramatics, ...plain power of personal example, main force of intellect and sometime even bullying" (p. xii; Epstein, 1981). They took lecturing seriously, and had high expectations of themselves as well as of their students (Epstein, 1981). Other characteristics described included being democratic, approachable, and knowledgeable; offering well prepared and structured lectures; ensuring subject relevance; encouraging questions and opinions from students; and evincing enthusiasm (Hildebrand et al., 1971; Sheffield, 1974; Uranowitz \& Doyle, 1978). Responses made by students were then summarized and clustered into closely related dimensions such as personal qualities or attributes and subject mastery, organization and presentation (Sheffield, 1974). These dimensions closely resemble the framework of modern student evaluation questionnaires of lecturers. Obviously, many of the currently utilized student rating forms have some of their roots in these earlier explorative studies.

A number of evaluative ratings and observational questionnaires, both structured and unstructured, have been completed by students and subjected to factor-analysis and meta-analysis procedures in order to identify specific lecture attributes. These analyses, in turn, have reported as many as sixteen and as few as two mathematically distinct attributes. For instance, from a total of 169 characteristics derived from observational techniques, Solomon, Rosenberg and Bezdek's (1964) factor analysis yielded eight factors: control versus permissiveness; lethargy versus energy; protectiveness versus aggressiveness; 
encouragement of student cognitive growth and participation; dryness versus flamboyance; coldness versus warmth; and vagueness versus clarity. The latter factor correlated highly with mean student gain in factual knowledge. Hildebrand et al., (1971) found the following attributes describing an effective lecturer: analytic-synthetic approach (emphasizing conceptual understanding, contrasting theories and implications); organization-clarity; and enthusiasmdynamism. Centra (1990) recently demonstrated factor structures - expressiveness, organization, clarity, task orientation and knowledge - as essential qualities underlying effective lecturing. In Seldin's (1980) review of evaluative studies. he found a sixteen factor analysis of instructor ratings, of which organization-clarity, enthusiasm-stimulation and group-instructional skill received the strongest loading in relation to student learning outcomes.

In a series of studies, Feldman $(1984 ; 1989)$ expanded the range of instructional dimensions that Cohen (1981) had initially observed in his meta-analysis, and preserved more of the information available in the evaluation of items and scales under review. Studies reviewed in which students generated their own characteristics yielded factors such as concern and respect for students, and impartiality; whereas studies utilizing check-off lists (i.e., structured questionnaires) yielded factors of intellectual challenge and sensitivity to class level and progress. For both methods, students ranked knowledge and stimulation dimensions most highly, with enthusiasm and ability to explain clearly, as important. Feldman's (1984) list of 28 categories provides the most extensive set of instructional characteristics that are likely to underlie the student evaluative questionnaire. In his advice to lecturers, he reduced his list down to the following essentials: clarity; preparation-organization; enthusiasm; interaction with students; and quality and frequency of feedback to students (see Feldman, 1989 Appendix B for a detailed description of each). He also found that a lecturer's pursuit of course objectives was highly correlated to student achievement, whereas elocutionary skills were only moderately related to student achievement.

According to the aforementioned correlational studies, effective lecturing is multidimensional. Each dimension identified some influence on student learning outcomes. However, if effective lecturer attributes influence student learning, the underlying cognitive processes activated need to be highlighted. In seeking empirical evidence that demonstrates a reliable link between these teaching qualities and important student outcomes, such as learning and motivation, information from studies other than correlational are necessary. Specifically, the laboratory analog ${ }^{\prime}$ offers important information regarding the 
Figure 1

Student information processing activities and behaviours linked to specific lecturing attributes
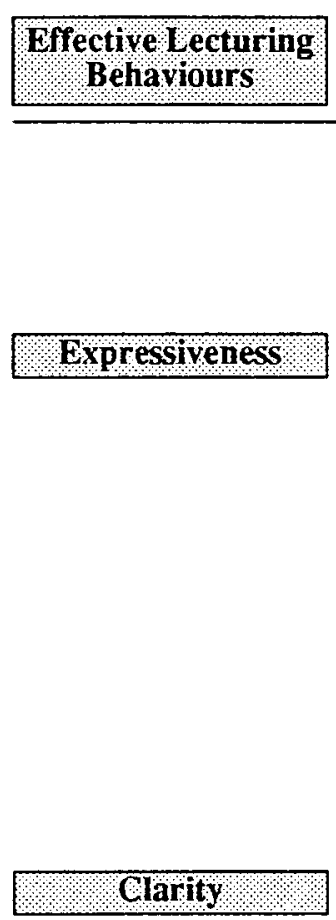

Organization

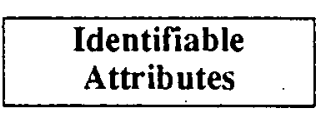

Eye Contact

Physical Movement
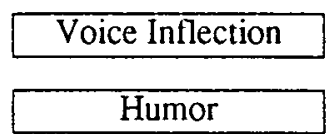

\begin{tabular}{|c|}
\hline High Energy \\
Enthusiasm
\end{tabular}

Outlines \& Diagrams

\begin{tabular}{|c|}
\hline $\begin{array}{c}\text { Concrete Examples } \\
\text { or Methaphors }\end{array}$ \\
\hline
\end{tabular}

Analogies \& Similes

\begin{tabular}{|c|}
\hline $\begin{array}{c}\text { Pictures \& Graphic } \\
\text { Models }\end{array}$ \\
\hline
\end{tabular}
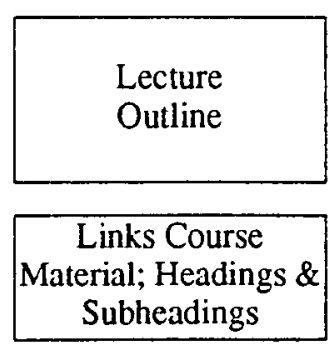

Syllabus
Student Information

Processing Activity

and Behaviour(s)

Intense Interest or

Challenge

Selective Altention

Selective Attention

Selective Attention

Additional Material Seeking Behaviours

Structural or Internal Relationships Among Ideas

Connectivitiy Between New \& Old Ideas

Verbal Elaborations

Imaginable Elaborations

Memory Storage Cues; Knowledge Structure; Schemata: Chunking

Cognitive Integration of Content Topics: Meaningfulness

Predictability 
causal relationships between teaching process and student outcomes. Lecturing dynamics can be subjected to scientific inquiry (Gage, 1978), particularly utilizing experimental and quasi-experimental designs (Schulman. 1986). In the following section, the major lecturer attributes will be defined and empirical evidence linking the attributes to specific student outcomes will be provided. Finally, the lecturer attributes are discussed in terms of their linkage to student cognitive mechanisms.

\section{Experimental Findings}

A large body of descriptive research findings on college lecturing presents a consistent picture of the outstanding lecturer. A number of behavioural attributes are repeatedly reported. These reoccurrences have prompted researchers to investigate further the different fundamental dimensions through empirical studies. The most common lecture attributes that are highly correlated with student outcomes will be addressed in further detail below. The order in which each dimension appears is indicative of the postulated relevance that each holds in activating the cognitive processes essential in student learning. Figure 1, a composite of Feldman (1989), Murray (1991), and Perry (1991), represents the links postulated to exist between effective lecturing behaviours and student cognitive processing.

Expressiveness $^{2} \quad$ According to Murray (1991), unless student attention has already been engaged by expressiveness. all other lecture attributes are less likely to be effective. Expressiveness is described in terms of intellectual excitement through communication and interpersonal skills (Lowman, 1984), charisma. rapport, dynamism, and personality (Perry, Abrami, \& Leventhal, 1979). Teacher enthusiasm or expressiveness is operationally defined by low-inference behaviours including movement while presenting material, gestures with hands and arms, eye contact with students, voice inflection, minimal reliance on lecture notes and humour that is relevant to lecture content (Murray, 1991; Perry, 1991). Numerous experimental studies have repeatedly demonstrated that expressiveness determines students' scholastic behaviours such as increasing achievement (Coats \& Smidchens, 1966; Mastin. 1963; Perry, 1991), increasing attendance to delayed lecture, and amount of homework completed (Perry \& Penner, 1990). Expressiveness also determines students' achievement-related behaviours, such as generating a more internal attributional orientation toward their achievement (i.e., ability/effort), increasing their self-esteem (i.e., self-confidence, self-competence) and motivation, and enhancing positive affect (see Schonwetter et al., 1993). Thus, expressiveness is not only correlated, but also 
causally linked to student achievement and achievement-related behaviours and is, therefore, an important lecturing behaviour.

From a cognitive point of view, expressiveness plays a pivotal role in classroom learning (see Figure 1). Providing general stimuli for optimum arousal through the stimulus cuing qualities associated with physical movement, voice intonation, eye contact, and humour, expressiveness is hypothesized to prime students' information processing by facilitating their selective attention (Murray, 1985; Williams \& Ware, 1976). Selective attention in turn, is crucial to most types of information processing (Kuhl, 1985; Mayer, 1987). As a general orienting stimulus, expressiveness indicates "pay attention"; "this material is interesting," and enables students to process relevant information, enhancing memory storage and retrieval (Perry, 1991). Apparently, eye contact is thought to create intense interest or to challenge the recipient (Perry, 1991), whereas the energy of an expressive instructor may be vicariously transferred to the student in the form of increased motivation for academic behaviours such as studying outside of the classroom (Murray, 1991). Despite their influence on student learning, the facilitative effects of organization and clarity are thought to achieve fruition only after student attention has already been successfully engaged (Murray, 1985). Thus, expressiveness is an example of a general orienting stimulus that influences students' cognitive behaviours; a behaviour that may be modelled outside the classroom by students; and the "gate keeper" of the student's information-processing system, which, once activated, allows for the influence of other lecturing behaviours.

A number of shortcomings are apparent in the expressiveness research literature. First, an important area of basic research on human memory has been neglected. Students' arousal level, a state due to the general orienting response, has not been investigated. According to Jenkin's (1979) memory model, when arousal is at an optimal level, students' recognition of cues should be enhanced, thereby enabling in-depth information processing. In other words, students optimally aroused by expressive instruction should be able to process information more deeply and in less time. Although different levels of achievement following expressive instruction have been demonstrated (see Perry, 1991), the investigation of behaviour directly related to student arousal has yet to be conducted.

Second. previous research on expressive instruction has failed to control other behaviours which may have confounded the results. For instance, the research on expressiveness specifically controlled the amount of expressiveness and lecture content presented. But none of the studies reported controlling for other teaching behaviours such as clarity and organization (see Perry 1991). 
Furthermore. the effects found for expressiveness may not generalize to other teaching behaviours that have been identified in the college classroom (e.g., Feldman, 1976; Murray, 1983). Thus. more research is required to understand the attributes of expressive lecturing behaviours.

Clarity Outstanding instructors present complex ideas and concepts and their connections in logical ways that are clear and easily understandable for students, especially those who know little about the material. Clarity of content assumes that the instructor has mastered the course content adequately. Behaviours denoting clarity include: "uses relevant and concrete examples", "asks questions", "synthesizes and summarizes material periodically", "repeats difficult points or ideas", "stresses important points", "writes key terms on board", "suggests practical application", "signals transitions from one topic to the next" and "suggests mnemonic aids" (Hines, Cruickshank \& Kennedy, 1985; Murray, 1991).

Empirical evidence reveals that the identification of important points and the signalling of topic transitions improved lecture retention (Land. 1979) and examination performance (Land \& Combs, 1981). Hines et al., (1985) found that the lower inference behaviours loading on the clarity dimension explained $52 \%$ of the variance of student achievement. In a recent meta-analysis of effective instruction studies. Feldman (1989) found a strong relationship between clarity and "understandableness," and student achievement $(\underline{r}=0.56)$. These results indicate the importance of presenting material clearly and in an understandable manner. Attempts to clarify the paradigms and strategies inherent in the subject matter are important steps instructors can take. Although a number of studies have demonstrated the relationship between clarity and student learning, further advances in the causal relationship are only possible by exposing clarity to the rigour of empirical research.

Cognitive integration of new stimulus material is thought to be directly related to clarity (see Figure 1). For instance, the use of outlines and diagrams may provide structural relationships among ideas, such as a schema of all the hardwood trees in Canada. The use of concrete examples or metaphors, on the other hand, assists students in finding connections between new concepts and previously stored knowledge (Murray, 1991). Examples in the forms of analogies, similes, and metaphors may help students to construct verbal elaborations whereas pictures, graphic models, concrete examples may help students to construct imaginable elaborations. According to Tulving (1979), the probability of recall is determined solely by the compatibility between trace information and retrieval information. Thus, an instructor who provides cues at the time of 
encoding (i.e.. during a lecture) that are clear and compatible with those given at the time of retrieval (i.e., test) should in essence be able to increase substantially the probability of information being recalled by students. When students' capacity to understand the course material is optimized, they will likely experience feelings of mastery and confidence (Perry, 1991). Therefore, clarity is postulated to play an important role in the encoding and storage stages of information processing which enhance and facilitate retrieval.

Organization Explicit organization of content facilitates the learning of subject matter (Kallison, 1986). Good organization of subject matter and planning of course material are important to student learning. Examples denoting organization include "the instructor planned the activities of each class period in great detail", "the overall development of the course had good continuity", "gives preliminary overview of lecture", "puts outline of lecture on board", "uses headings and subheadings", and "signals transitions to a new topic" (Feldman, 1989; Murray, 1991). The organized instructor has a well structured method of lecturing which breaks the course into units more readily accessible to processing on the part of students (Perry, 1991).

Highly structured teaching has been demonstrated to produce significantly higher achievement scores than less structured teaching (Guetzkow, Kelley, \& McKeachie, 1954). Feldman (1989) found a high correlation between teachers' preparation and organization of the course and students' achievement $(r=0.57)$, accounting for at least $10 \%$ of the variance. Centra (1987) includes good organization of subject matter and course as an important teaching variable. However, as with clarity, research on organization tends to be dominated by correlational studies, thereby limiting the extent to which the causal effect of instructional behaviour on student learning can be implied.

Organization of course material, as demonstrated through well structured presentations, syllabus, and lecture outline, may act as a specific orienting stimulus as well as providing students with "chunking" strategies (see Figure 1; Perry. 1991). As a specific orienting stimulus, organization can provide cues for what is considered relevant and needs to be recorded. For example, lecture outline notes presented on the blackboard, flip chart, handout, or overhead have a higher probability of being recorded, a factor which in turn significantly improves students' achievement scores (Hartley \& Cameron, 1967; Hartley \& Fuller. 1971; Howe \& Godfrey, 1977; Maddox \& Hoole, 1975). In addition to being a specific stimulus cue, organization in the form of outlines represents a knowledge structure. This knowledge structure, in turn, provides a "chunking" strategy, a quick and logical method of structuring lecture material 
(Perry, 1991), which influences comprehension (Meyer, 1975;1977) and facilitates encoding and retrieval of learning material (Glynn \& Di Vesta, 1977).

\section{Lecturing Attributes Summarized}

Expressiveness, clarity, and organization all play an important role in student learning. Expressiveness, or the general orienting stimulus, elicits students' attention, whereas clarity and organization facilitate information processing and recall of lecture material. Given that selective attention. encoding and retrieval are all important components of student learning, and that effective teaching behaviours are hypothesized to be directly related to these cognitive components, then for learning to be optimal, each behaviour needs to be engaged. In other words, the absence of any one of these behaviours should be reflected in a hindrance of the related cognitive process. Ideally, exposure to highly expressive, clear and well-organized lectures should produce optimal learning for the student. Thus, lecturers in their pursuit of helping students learn, should focus more on a number of important behaviours, such as expressiveness, clarity, and organization. However, no study has empirically demonstrated the significance of the interaction of these three behaviours on student learning and cognitive processing activities.

Although a number of cognitive researchers have postulated how the lecturing process is linked to student outcomes via underlying cognitive processes, it remains yet to be determined whether these hypotheses are valid or if other cognitive processes, yet undiscovered, are responsible in linking lecturing with learning outcomes. Only additional research can unravel the mystery of the interaction of these effective teaching behaviours with student learning.

\section{Implications for Higher Education}

The ultimate test of any effective lecturing dimension is the extent to which it can be successfully applied to the improvement of pedagogy. Progressing from poor to adequate lecturing requires eliminating specific behavioural weaknesses. Therefore, feedback for poorer lecturers can lead to significant improvement in perceived lecturing effectiveness (Sullivan, 1983). For instance, a group of instructors trained on a limited set of behaviours known to contribute substantially to overall lecturing effectiveness (e.g., vocal variation, facial expression, movement and gesture, use of pauses for emphasis) demonstrated significant gains in student ratings from pre- to post-test, indicating that behavioural training produced significant improvement in classroom instruction effectiveness (Murray \& Lawrence, 1980). Finally, a training workshop focusing on 
low-inference teaching behaviours (e.g., clarity of explanation in lecturing) demonstrated significant gains in effective lecturing from pre- to post- workshop student ratings (Brown, 1982). Therefore, focusing on low-inference lecturing behaviours in training programs has proven to be effective. As Murray (1991) states, more research is needed on the impact and generalization of effective lecturing behaviour training for instructors.

\section{Implications for the Future}

Future research in lecturing effectiveness can take a number of directions: cross-discipline, cross-lecturer within the same discipline and same course, and cross-lecturing methods. Research is needed to determine whether lecturing behaviours identified as important in the social sciences are equally important in other disciplines, and in teaching behaviours other than the lecture method. It would also be interesting to know why and how instructors select certain lecturing behaviours and ignore others. Important conclusions providing guidelines on how to train or select college instructors. how to evaluate lecturing, and how to improve the performance of current lecturers are needed. These guidelines would be of benefit for the designing of in-service faculty development programs that focus on a specific set of relevant lecturing behaviours known to contribute significantly to overall lecturing effectiveness.

\section{Notes}

1 ... which addresses both types of validity, internal and external (Perry, 1991). Internal validity is demonstrated through the control of external variables and external validity is apparent through the experimental realism as demonstrated by "the direct manipulation of instruction as an independent variable, the random assignment of subjects to experimental conditions and the precise measurement of educational outcomes" (Perry, 1991; p. 21).

2 A definitional issue has arisen between researchers regarding this dimension. Feldman (1989) tends to argue from a statistical background, that behaviours defining this dimension are those that have been factor analyzed as relating (i.e., "clarity in presentation"; "instructor shows energy and excitement") and thus has called this "factor enthusiasm." Perry (1991) has approached the development of this construct from a theoretical approach, defining this dimension as those behaviours that are theoretically related in enhancing students' selective attention (i.e., voice intonation, humour, physical movement. eye contact), and therefore, has called it "expressiveness." Both terms, although having different conceptual generation, have been used to denote the same teaching behaviour, and thus will be used interchangeably. 


\section{References}

Abrami, P.C. (1983). Dimensions of effective college instruction. Paper presented at the American Educational Research Association, Montreal.

Bolton, B., Bunge, D., \& Marr, J. (1979). Ratings of instruction, examination performance, and subsequent enrollment in psychology courses. Teaching of Psychology, 6, 82-85.

Brown, G.A. (1982). Two days on explaining and lecturing. Studies in Higher Education, 7, 93-103.

Cashin, W.E. (1988). Student ratings of teaching: A summary of research. (IDEA paper no. 20). Kansas State University, Division of Continuing Education (ERIC Document Reproduction Service No. ED 289 935).

Centra, J.A. (1987). Formative and summative evaluation: Parody or paradox? New Directions for Teaching and Learning, 31, 47-55.

Centra, J.A. (1990). Faculty evaluation and faculty development. In J. Smart (Ed.), Higher Education: Handbook of theory and research (vol. 6). New York: Agathon.

Coats, W.D., \& Smidchens, U. (1966). Audience recall as a function of speaker dynamisin. Journal of Educational Psychology, 57, 189-191.

Cohen, P.A. (1981). Student rating of instruction and student achievement: A metaanalysis of multisection validity studies. Review of Educational Research, 51, 281309.

Donald, J.G. (1983). Knowledge structures: Methods for exploring course content. Journal of Higher Education, 54, 31-41.

Donald, J.G. (1985). The state of research on university teaching effectiveness. In J.G. Donald \& A.M. Sullivan (Eds.), Using research to improve teaching: New directions for teaching and learning. (pp.7-20). San Francisco: Jossey-Bass.

Doyle, K.O. (1983). Evaluating teaching. Toronto: Lexington Books.

Dunkin, M.J., \& Barnes, J. (1986). Research on teaching in higher education. In M. Wittrock (Ed.), Third handbook of research on teaching (pp. 754-777). New York: Macmillan.

Epstein, J. (1981). Masters: Portraits of great teachers. New York: Basic Books.

Feldman, K.A. (1976). The superior college teacher from the students' view. Research in Higher Education, 5, 243-288.

Feldman, K.A. (1984). Class-size and students' evaluation of college teachers and courses: A closer look. Research in Higher Education, 21, 45-116.

Feldman, K.A. (1989). The association between student ratings of specific instructional dimensions and student achievement: Refining and extending the synthesis of data from multisection validity studies. Research in Higher Education, 30, 583-645.

Gage. N.L. (1978). The scientific basis of the art of teaching. New York: Teachers College Press, Columbia University.

Gigliotti, R.J. \& Buchtel, F.S. (1990). Attribution bias and course evaluations. Journal of Educational Psychology, 82, 341-351.

Glynn, S.M., \& Di Vesta, F.J. (1977). Outline anhierarchial organization as aids for study and retrieval. Journal of Educational Psychology, 69, 89-95. 
Guetzkow, H.S., Kelley, E.L., \& McKeachie, W.J. (1954). An experimental comparison of recitation, discussion, and tutorial methods in college teaching. Journal of Educational Psychology, 45, 193-209.

Hartley, J., \& Cameron, A. (1967). Some observations on the efficiency of lecturing. Educational Review, 20, 30-37.

Hartley, J., \& Fuller, H. (1971). The use of slides in lectures: An exploratory study. Visual Education, August-September, 39-41.

Howe, M.J.A., \& Godfrey, J. (1977). Student notetaking as an aid to learning. Exeter, England: Exeter University Teaching Services Department.

Hildebrand, M., Wilson, R.C., \& Dienst, E.R. (1971). Evaluating university teaching. Berkeley: Center for Research and Development in Higher Education, University of California.

Hines, C.V., Cruickshank, D.R.. \& Kennedy. J.J. (1985). Teacher clarity and its relationship to student achievement and satisfaction. American Educational Research Journal, 22, 87-99.

Jenkins, J.J. (1979). Four points to remember: A tetrahedral model of memory experiments. In L.S. Cermak \& F.I.M. Craik (Eds.), Levels of processing in human mentory. Hillside, N.J.: Lawrence Erlbaum Associates.

Kallison. J.M., Jr. (1986). Effects of lesson organization on achievement. American Educational Research Journal, 23, 337-347.

Kuhl, J. (1985). Volitional mediators of cognitive-behavioral consistency: Selfregulatory processes and action versus state orientation. In J. Kuhl \& Beckmann (Eds.), Action control: From cognition to behavior (pp. 101-128). New York: Springer-Verlag.

Land, M.L. (1979). Vagueness and clarity in the classroom. In T. Husen \& T.N. Postlethwaite (Eds.), International encyclopedia of education: Research and studies. Oxford: Pergamon Press.

Land, M.L., \& Combs, A. (1981). Teacher clarity, student instructional ratings, and student performance. Paper presented at annual meeting of American Educational Research Association, Los Angelos.

Leventhal, L., Abrami, P.C., Perry, R.P., \& Breen, L.J. (1975). Section selection in mulit-section courses: Implications for the validation and use of student rating forms. Educational and Psychological Measurement, 35, 885-895.

Lowman, J. (1984). Mastering the techniques of teaching. London: Jossey-Bass Publications.

Maddox, H., \& Hoole, E. (1975). Performance decrements in the lecture. Educational Review, 28, 17-30.

Marsh, H.W. (1983). Multidimensional ratings of teaching effectiveness by students from academic settings and their relation to student/course/instructor characteristics. Journal of Educational Psychology, 75, 150-166.

Marsh, H. (1984). Students ' evaluations of university teaching: Dimensionality, reliability, validity, potential biases, and utility. Journal of Educational Psychology, 76, 707-754. 
Marsh, H.W., \& Dunkin, M.J. (1991). Students' evaluations of university teaching: A multidimensional perspective. In J. Smant (ed.), Higher Education: Handbook of theory and research. (vol 9) New York: Agathon.

Marsh, H.W., \& Overall, J.U. (1980). Validity of students' evaluation of teaching effectiveness: Cognitive and affective criteria. Journal of Educational Psychology, $72,468-475$.

Mastin, V.E. (1963). Teacher enthusiasm. Journal of Educational Research, 56, 385. 386.

Mayer, R.E. (1987). Information processing variables in learning to solve problems. Review of Educational Research, 45, 525-541.

McKeachie, W.J. (1980a). Implications of cognitive psychology for college teaching. New Directions for Teaching and Learning, 2, 85-93.

McKeachie, W.J. (1980b). Improving lectures by understanding students' information processing. New Directions for Teaching and Learning, 2, 25-35.

McKeachie, W.J. (1987). Instructional evaluation: Current issues and possible improvements. Journal of Higher Education, 58, 344-350.

McKeachie, W.J. (1990a). Learning, thinking, and Thorndike. Educational Psychologist, 25(2), 127-141.

McKeachie, W.J. (1990b). Research on college teaching: The historical background. Journal of Educational Psychology, 82, 189-200.

McKeachie, W.J., Pintrich, P.R., Lin, Y.G., Smith, D.A.F. (1986). Teaching and learning in the classroom: A review of the literature. Ann Arbor: University of Michigan Publication.

Meyer, B.J.F. (1975). The organization of prose and its effects on memory. Amsterdam: North-Holland Publishing Co.

Meyer, B.J.F. (1977). The structure of prose: Effects on learning and memory and implications for educational practice. In R. C. Anderson, R. J., Spiro, \& W. E. Montage (Eds.), Schooling and acquisition of knowledge (pp. 179-200). Hillsdale, NJ: Lawrence Erlbaum Associates, Inc.

Murray, H.G., \& Lawrence, C. (1980). Speech and drama training for lecturers as a means of improving university teaching. Research in Higher Education, 13, 73-90.

Murray, H.G. (1983). Low-inference classroom teaching behaviors and student ratings of college teaching effectiveness. Journal of Educational Psychology, 75, 138-149.

Murray, H.G. (1985). Classroom teaching behaviors related to college teaching effectiveness. In J.G. Donald \& A.M. Sullivan (Eds.), Using research to improve teaching: New directions for teaching and learning. (pp. 21-34).San Francisco: Jossey-Bass.

Murray, H.G. (1991). Effective teaching behaviors in the college classroom. In J. Smart (Ed.), Higher education: Handbook of theory and research (Vol. 7). New York: Agathon Press.

Perry, R.P. (1985). Instructor expressiveness: Implications for improving teaching. In J. Donald and A. Sullivan (Eds.), Using research to improve teaching (pp. 35-49). San Francisco: Jossey-Bass. 
Perry, R.P. (1991). Perceived control in college students: Implications for instruction in higher education. In J. Smart (Ed.), Higher education: A handbook of theory and research (Vol.7). (pp.1-56). New York: Agathon.

Perry, R.P., Abrami, P.C., \& Leventhal. L. (1979). Educational seduction: The effect of instructor expressiveness and lecture content on student ratings and achievement. Journal of Educational Psychology, 71, 109-116.

Perry, R.P., \& Penner, K.S. (1990). Enhancing academic achievement in college students through attributional retraining and instruction. Journal of Educational Psychology, $82,262.271$.

Rosenshine, B., \& Furst, N.F. (1971). Research on teacher performance criteria. In B.O. Smith (Ed.), Research in teacher education: A symposium. Englewood Cliffs, New Jersey: Prentice Hall.

Schonwetter, D.J., Perry, R.P., \& Struthers, C.W. (1993). The role of instruction and cognition for college students academic achievement and affects. Journal of Experimental Education, winter.

Schulman, L.S. (1986). Paradigms and research programs in the study of teaching: A contemporary perspective. In M. Wittrock (Ed.), Third handbook of research on teaching. New York: Macmillian.

Seldin, P. (1980). Successful faculty evaluation programs. New York: Coventry Press.

Sheffield. E.F. (Ed.), (1974). Teaching in universities: No one way. Montreal: McGillQueen's University Press.

Solomon. D., Rosenberg, L., \& Bezdek. W.E. (1964). Teacher behavior and student learning. Journal of Educational Psychology, 55, 23-30.

Sullivan, A.M. (1983). The improvement of university teaching. Canadian Psychology, 24, 119-124.

Tulving. E. (1979). Relations between encoding specificity and levels of processing. In L.S. Cermak \& F.I.M. Craik (Eds.), Levels of processing in human memory. Hillside, N.J.: Lawrence Erlbaum Associates.

Uranowitz, S.W., \& Doyle, K.O. (1978). Being liked and teaching: The effects and bases of personal likability in college instruction. Research in Higher Education, 9, $15-41$.

Williams, R.G., \& Ware, J.E. (1976). Validity of student ratings of instruction under different incentive conditions: A further study of the Dr. Fox effect. Journal of Educational Psychology, 68, 48-56.

Wotruba, T.R., \& Wright, P.L. (1974). How to develop a teacher-rating instrument: A research approach. Journal of Higher Education, 46(6), 653-663. 